\title{
Socialization of Undergraduate Medical Students in Bangladesh: Students' and teachers' view
}

\author{
Brig Gen Dr. Taufiqul Hasan Siddiquee ${ }^{\prime}$, Dr. Tahmina Nargis ${ }^{2}$, Prof. Dr. Md. Humayun Kabir Talukder ${ }^{3}$
}

\begin{abstract}
This descriptive type of cross sectional mixed method study was conducted with four specific objectives to understand the perception, area, ways and barriers in socialization of undergraduate medical students in Bangladesh. The study was conducted in 8 (eight) medical colleges of which 6 (six) are public and 2 (two) are private. The study was conducted for one year from July 2017 to June 2018. Total 712 student of final phase participated in the study. In- depth interview was conducted with teachers. Convenience sampling technique for selection of the students whereas medical colleges were selected purposefully.

Study revealed that most of the asked parameters related to patient care and humanistic attitude was taught to the undergraduate medical students of the selected medical colleges in Bangladesh. There are few concerns though in some area like number of role models and presence of negative role models among the teachers. Contents, aim and objectives of the current curriculum is vastly unknown to teachers.

A conscious attempts to be made to transform medical students in a positive manner. Teachers should be selected following a proper career planning and they should undergo some kind of courses before deployment which would give them an understanding on teaching methodology and capability to foster ethically compatible as well as technically skill medical students of current era.
\end{abstract}

Key Words: Socialization, professionalism, undergraduate curriculum, undergraduate medical students

\section{Introduction}

Socialization involves the moral and symbolic transformation of a lay person into an individual who can take on the special role and status claimed by the profession (Haas and Shaffir 1982). Through the process of socialization an amateur person becomes a doctor equipped with professional distinctiveness and values (Han et al. 1996). Socialization generally refers to the process through which an individual is adapted in the society to perform his/her role determined by the society itself. The socialization of medical students into the medical profession is more than the acquisition of a body of knowledge, attitudes and skills, proven through the passing of examinations. Medical students must learn how to be a doctor, that is, the 'craft' of medicine, which goes beyond the application of medical knowledge (Conrad 1988). To practice medicine students need to develop a professional identity i.e. ways of being and relating in professional contexts. Identity is

1. Commandant, Combined Military Hospital $(\mathrm{CMH})$ Dhaka Cantonment, Dhaka

2. Professor, Curriculum Development \& Evaluation, Centre for Medical Education, Mohakhali, Dhaka

3. Associate Professor, Education Science, Centre for Medical Education, Mohakhali, Dhaka

Address of correspondence:

Brig Gen Dr. Taufiqul Hasan Siddiquee

Commandant, Combined Military Hospital (CMH)

Dhaka Cantonment, Dhaka.

Email: taufiq660@gmail.com realized through a dynamic process of identification by which individuals classify their place in the world as both individuals and members of collectives. It develops in interactional relationships during which individuals may be influenced more by the categorizations of others than her/his own cognitions and emotions (Ashmore et al. 2004).

While students' socialization occurs through formal teaching, informal instruction is more influential. Examples include role modelling, tacit behavior (Coulehan and Williams 2000). Medical society requires people to interact with each other for its norms, values and roles to be actualized and students encounter medical society when interacting with people from it. The communities of practice encountered often contain members of other groups e.g. scientists, laboratory staff, nurses, other health care professionals, ancillary staff and patients. They also encounter communities of practice whose members are exclusively from these different groups. (Goldie 2012)

Medical students obtain certain values and identity informally. Socialization and professionalism are interwoven together like Siamese twins. Medical students socialize through seeing and learning from the surroundings. He should stay under the radar, find and cultivate the wisest mentors, stand behind the pillars of the community, and gain their trust for several years. This study aims to understand the socialization of undergraduate medical students of Bangladesh which actually prepares them to fit in to the society of professionals with high moral and ethical values.

Bangladesh Journal of Medical Education 2019;10(1):14-19. (C) 2019 Siddiquee et al., publisher and licensee Association for Medical Education. This is an Open Access article which permits unrestricted non-commercial use, provided the original work is properly cited. 


\section{Material and Methods}

This was a mix method descriptive type of cross sectional study. Study period was 12 months from July 2017 to June 2018. Study area was eight medical colleges of Bangladesh of which four were in Dhaka and four were outside Dhaka. Six are government and two are non-government medical college. Out of eight medical college 4 (four) are inside and 4 (four) are outside Dhaka. All the students of $4^{\text {th }}$ phase and clinical teachers were included as study population. Sample size was 712 students and 10 clinical teachers. A selfadministered semi structured questionnaire was used to collect opinion of the students. Likert scale was used. Indepth interview was conducted with teachers. Medical Colleges were selected purposefully, and convenience sampling technique was for selection of the students.

\section{Results}

Table 1: Distribution of the student by gender and type of medical college

\begin{tabular}{|c|c|c|c|}
\hline \multicolumn{4}{|c|}{ Type of medical college } \\
\hline Gender & Government No. (\%) & Non-Government No. (\%) & Total No. (\%) \\
\hline Male & $177(33.5 \%)$ & $62(33.7 \%)$ & $239(33.6 \%)$ \\
\hline Female & $351(66.5 \%)$ & $122(66.3 \%)$ & $473(66.4 \%)$ \\
\hline Total & $528(100 \%)$ & $184(100 \%)$ & $712(100 \%)$ \\
\hline
\end{tabular}

Table 1 shows the distribution of the respondents' by gender and government and non-government medical colleges. In case of government medical college male students are $177(33.5 \%)$ and female students are $351(66.5 \%)$ whereas in non-government medical college this is 62(33.7\%) and $122(66.3 \%)$ for male and female respectively.

Table 2: Distribution of the students as per their views in relation to learning of ethical behavior about patient care

\begin{tabular}{|c|c|c|c|c|c|c|c|}
\hline \multirow[t]{2}{*}{ Statements in relation to learning of ethical behavior } & \multicolumn{5}{|c|}{ Level of agreement/ disagreement } & \multirow[t]{2}{*}{ Mean \pm SD } & \multirow[t]{2}{*}{ Total } \\
\hline & SDA & DA & UD & $\mathbf{A}$ & SA & & \\
\hline $\begin{array}{l}\text { I have been taught to practice ethical standards in the } \\
\text { patient care. }\end{array}$ & $6(0.8)$ & $7(1.0)$ & $9(1.3)$ & $225(31.7)$ & $463(65.2)$ & $4.59 \pm 0.65$ & 710 \\
\hline $\begin{array}{l}\text { I have learnt about the "Geneva declaration/ } \\
\text { Hippocratic oath" during study in previous phases. }\end{array}$ & $6(0.9)$ & $29(4.1)$ & $18(2.6)$ & $235(33.3)$ & $417(59.1)$ & $4.46 \pm 0.81$ & 705 \\
\hline $\begin{array}{l}\text { I have learnt to understand the patient's non-medical } \\
\text { problems and consider it in the consultation }\end{array}$ & $6(0.8)$ & $20(2.8)$ & $33(4.7)$ & $291(41.0)$ & $359(50.6)$ & $4.38 \pm 0.78$ & 709 \\
\hline $\begin{array}{l}\text { I have been taught about respecting confidentiality of } \\
\text { patients treatment. }\end{array}$ & - & $7(1.0)$ & $5(0.7)$ & $200(28.3)$ & 494(70.0) & $4.67 \pm 0.54$ & 706 \\
\hline $\begin{array}{l}\text { I have been taught to explain given treatment, informing } \\
\text { lab test result, and counselling to all patients and } \\
\text { relatives }\end{array}$ & $10(1.4)$ & $39(5.5)$ & $35(4.9)$ & $333(46.9)$ & $293(41.3)$ & $4.21 \pm 0.88$ & 710 \\
\hline $\begin{array}{l}\text { I have been told to avoid unethical behavior in relation } \\
\text { to accepting personal gifts from Pharmacetical } \\
\text { companies }\end{array}$ & $42(5.9)$ & $72(10.2)$ & $91(12.8)$ & 264(37.2) & $240(33.9)$ & $3.83 \pm 1.17$ & 709 \\
\hline $\begin{array}{l}\text { I have been told not to accept percentage/commission for } \\
\text { ordering laboratory test for patients from the clinic/ } \\
\text { private hospitals as it is unethical. }\end{array}$ & $39(5.5)$ & $66(9.4)$ & $58(8.2)$ & $269(38.2)$ & $273(38.7)$ & $3.95 \pm 1.16$ & 705 \\
\hline $\begin{array}{l}\text { I have learnt to consider patients as a" human being” by } \\
\text { our teachers. }\end{array}$ & $8(1.1)$ & $26(3.7)$ & $29(4.1)$ & $238(33.7)$ & $406(57.4)$ & $4.43 \pm 0.83$ & 707 \\
\hline I have learnt to manage patients impartially & $6(3.7)$ & $22(3.1)$ & $24(3.4)$ & $259(36.7)$ & $375(53.1)$ & $4.32 \pm 0.96$ & 706 \\
\hline
\end{tabular}

SDA: Strongly disagree, DA: Disagree, UD: Undecided, A: Agree, SA: Strongly agree 
Table 2 shows the opinion of the respondents about learning of ethical behaviors. There were 9 (nine) items in this table to clarify part of this behaviors. Of the respondents $65.2 \%$ strongly agreed and $31.7 \%$ agreed that they have learnt the practice of ethical behavior in patient care. Regarding respecting the value of confidentiality of patients $70.0 \%$ respondent strongly agreed and $28.3 \%$ agreed that they have learnt the value of it. Regarding explaining given treatment or informing test result or counselling $41.3 \%$ strongly agreed and $46.9 \%$ agreed that they have been taught during their learning in the medical schools. Regarding unethical behavior in relation to accepting personal gifts from pharmaceutical companies $33.9 \%$ strongly agreed and 37.2\% agreed that they have been told about this in their learning phases. 38.7\% respondent strongly agreed and $38.2 \%$ agreed that they have been told about accepting percentage or commission for ordering laboratory investigation as it is considered unethical. Regarding managing a patient impartially without considering his social status $53.1 \%$ strongly agreed and $36.7 \%$ agreed that they have learnt this age old medical norms during their course of study.

Table 3: Distribution of the students as per views in relation to learning to communicate with teachers, patients, peers and team members

\begin{tabular}{|c|c|c|c|c|c|c|c|}
\hline \multirow[t]{2}{*}{ Statements in relation to Communication } & \multicolumn{5}{|c|}{ Level of agreement/ disagreement } & \multirow[t]{2}{*}{ Mean \pm SD } & \multirow[t]{2}{*}{ Total } \\
\hline & SDA & DA & UD & $\mathbf{A}$ & SA & & \\
\hline $\begin{array}{l}\text { I have been taught to control my angers in adverse } \\
\text { situations during management of patients. }\end{array}$ & $26(3.7)$ & $53(7.5)$ & $59(8.3)$ & $341(48.0)$ & $231(32.5)$ & $3.98 \pm 1.02$ & 710 \\
\hline $\begin{array}{l}\text { I have learnt to maintain good relationship with the team } \\
\text { members }\end{array}$ & $13(1.8)$ & $37(5.3)$ & $56(8.0)$ & $364(51.8)$ & $233(33.1)$ & $4.09 \pm 0.88$ & 703 \\
\hline $\begin{array}{l}\text { I am aware about Teacher-Student relationship which is } \\
\text { congenial and motivating to learn }\end{array}$ & $21(3.0)$ & $24(3.4)$ & $40(5.6)$ & $341(48.2)$ & $282(39.8)$ & $4.19 \pm 0.91$ & 708 \\
\hline $\begin{array}{l}\text { I have learnt not to criticize fellow physicians and their } \\
\text { prescriptions }\end{array}$ & $16(2.3)$ & $51(7.2)$ & $47(6.6)$ & $304(42.9)$ & $291(41.0)$ & $4.13 \pm 0.98$ & 709 \\
\hline $\begin{array}{l}\text { I have learnt the procedure and art of breaking bad news } \\
\text { to the patients and relatives. }\end{array}$ & $36(5.1)$ & $102(14.5)$ & $85(12.1)$ & $287(40.8)$ & $194(27.6)$ & $3.71 \pm 1.16$ & 704 \\
\hline $\begin{array}{l}\text { I have learnt to avoid informal dress during ward rounds } \\
\text { or attending patients }\end{array}$ & $15(2.1)$ & $37(5.2)$ & $37(5.2)$ & $285(40.3)$ & $333(47.1)$ & $4.25 \pm 0.93$ & 707 \\
\hline
\end{tabular}

Table 3 shows the opinion of the respondents in relation to learning to communicate with teachers, patients, peers and team members. There are 6 (six) items in this table. Regarding controlling of angers during adverse situation in patient management $32.5 \%$ strongly agreed and $48.0 \%$ respondent agreed that they have been taught about this art. In regards to maintaining good relationship with the team members $33.1 \%$ strongly agreed and $51.8 \%$ agreed that they have learnt it during their course of study. Regarding congenial teacher and student relationship 39.8\% strongly agreed and $48.2 \%$ agreed that they are aware about this motivating factor of learning. About learning the art of breaking bad news $27.6 \%$ strongly agreed and $40.8 \%$ agreed positively.

Table 4: Distribution of the students on the basis of ways of learning of ethical behavior and communication skill

\begin{tabular}{lcc}
\hline Ways of learning & Frequency & Percent \\
\hline Lecture & 508 & 71.3 \\
Ward rounds & 577 & 81.0 \\
Informal discussions & 325 & 45.6 \\
Observing role models & 251 & 35.3 \\
During Residential field site & 95 & 13.3 \\
training ( RFST) & & \\
Never taught formally & 65 & 9.1 \\
\hline
\end{tabular}

Multiple responses

Table 4 Distribution of the students on the basis of ways of learning ethical behavior and communication skills. This multiple response item showed that $577(81.0 \%)$ respondent learns it during word rounds, lecture $508(71.3 \%)$, informal discussions $325(45.6 \%)$ and by observing role models $251(35.5 \%)$.
Table 5: Distribution of the students on the basis of noticing of humiliation of Students, Staffs and Patients by teachers/ doctors in front of other students patients/relatives

\begin{tabular}{lccc}
\hline $\begin{array}{l}\text { Noticed abusing/ } \\
\text { humiliation }\end{array}$ & $\begin{array}{c}\text { Humiliation } \\
\text { of Students }\end{array}$ & $\begin{array}{c}\text { Humiliation } \\
\text { of Staffs }\end{array}$ & $\begin{array}{c}\text { Humiliation } \\
\text { of Patients }\end{array}$ \\
\hline Yes & $496(70.4)$ & $397(57.0)$ & $348(54.7)$ \\
No & $209(29.6)$ & $300(43.0)$ & $288(45.3)$ \\
Total & $\mathbf{7 0 5 ( 1 0 0 . 0 )}$ & $\mathbf{6 9 7 ( 1 0 0 . 0 )}$ & $\mathbf{6 3 6 ( 1 0 0 . 0 )}$ \\
\hline
\end{tabular}

Table 5 shows the distribution of the respondents on the basis of noticing abuse of students, staffs and patients by teachers/ doctors in front of the patients or relatives. Most of the respondents noticed abusing of students $(70.4 \%)$, staffs $(57.0 \%)$ and patients $(54.7 \%)$ in front of other students or patients/relatives by the doctors.

Bangladesh Journal of Medical Education 2019;10(1):14-19 
Table 6: Distribution of the students as per their views about the observed behaviors of 'Role Model'nt given and group dynamics df instruction is lecture

\begin{tabular}{lcc}
\hline Attributes & Frequency & Percent \\
\hline Good relationship with patients & 588 & 82.6 \\
Clinical expertise & 634 & 89.0 \\
Humanity & 552 & 77.5 \\
Personal attributes & 437 & 61.4 \\
Lifestyle & 253 & 35.5 \\
Good leadership Skills & 313 & 44.0 \\
Positive outlooks & 450 & 63.2 \\
\hline
\end{tabular}

Multiple responses

Table 6 shows the distribution of the respondents as per their views about observed attributes of the 'role model'. Clinical expertise $(89.0 \%)$, relationship with the patients $(82.6 \%)$, humanity $(77.5 \%)$, positive outlooks $(63.2 \%)$ and personal attributes $(61.4 \%)$ are considered as the determining attributes of a role model.

Table 7: Opinion of the students about perceived presence of Positive 'Role Models' and negative 'Role Models' among the Teachers

\begin{tabular}{lcc}
\hline $\begin{array}{l}\text { Perceived presence } \\
\text { of 'Role Models' }\end{array}$ & $\begin{array}{c}\text { Positive 'Role } \\
\text { Models' }\end{array}$ & $\begin{array}{c}\text { Negative 'Role } \\
\text { Models' }\end{array}$ \\
\hline Yes & $651(93.1)$ & $532(76.7)$ \\
No & $48(6.9)$ & $162(23.3)$ \\
Total & $\mathbf{6 9 9}(\mathbf{1 0 0 . 0})$ & $\mathbf{6 9 4}(\mathbf{1 0 0 . 0 )}$ \\
\hline
\end{tabular}

Table 7 depicts the opinion of the respondents about perceived presence of positive or negative Role models. 651(93.1\%) respondents' perceived that there are positive role models among teachers and 532(76.7\%) perceived that there are negative role models among their teachers.
Table 8: Distribution of the students as per their views about percieved barriers in becoming noble professional

\begin{tabular}{|l|c|c|}
\hline Barriers & Frequency & Percent \\
\hline $\begin{array}{l}\text { Non congenial academic } \\
\text { environment }\end{array}$ & 329 & 46.2 \\
\hline Non congenial hostel environment & 302 & 42.4 \\
\hline $\begin{array}{l}\text { Non supportive Socio political } \\
\text { environment }\end{array}$ & 384 & 53.9 \\
\hline Lack of competent teachers & 354 & 49.7 \\
\hline Family burden & 143 & 20.1 \\
\hline $\begin{array}{l}\text { Lack of supervision from the } \\
\text { authority }\end{array}$ & 317 & 44.5 \\
\hline Lack of role model for students & 341 & 47.9 \\
\hline $\begin{array}{l}\text { Observing un ethical practice in } \\
\text { college/hospital wards }\end{array}$ & 307 & 43.1 \\
\hline Workload in the hospitals & 271 & 38.1 \\
\hline Overload with information/study & 201 & 28.2 \\
\hline $\begin{array}{l}\text { Lack of behavioral teaching by the } \\
\text { teachers }\end{array}$ & 271 & 38.1 \\
\hline $\begin{array}{l}\text { Lack of practical teaching about } \\
\text { Ethics, values and attitude }\end{array}$ & 313 & 44.0 \\
\hline
\end{tabular}

Multiple responses

Table 8 shows the distribution of the respondents as per their views about perceived barriers in becoming noble professional. Respondent perceived non-supportive political environment $384(53.9 \%)$, lack of competent teachers $354(49.7 \%)$, lack of role models $341(47.9 \%)$, noncongenial academic environment $302(46.2 \%)$, lack of supervision from the authority $317(44.5 \%)$ and lack of practical teaching about ethics $313(44.0 \%)$ are the main barriers to become a noble professional.

\section{In-depth interview with the teachers explore the following-}

Teaching background:

All of the interviewed faculties joined as teacher directly without any prior training on teaching methodology. They 'grow up' as teacher on the process following the seniors and other teachers. None are 'Intentional teacher".

"I have no intention to become a teacher....... I grew up as a teacher without formal knowledge..... am not an intentional teacher but I have learnt it on the process of my teaching and through my examinations in postgraduate courses and by following my teachers"

\section{Knowledge about existing curriculum and socialization process mentioned in curriculum:}

All the respondents agreed that they have little or shallow knowledge about the detail undergraduate curriculum. They have some knowledge about the pertinent portion relevant to their subject only. None have detail idea about the socialization and ethical goals to be achieved by the students mentioned in the curriculum. 


\section{Socialization rituals in the institutions:}

Oath taking in a modified form of 'Hippocratic oath' takes place in few colleges but most of the colleges follow only a briefing and orientation session for the parents and students. There is no socialization rituals takes place like 'white coat ceremony"

\section{Barrier/problems in socialization:}

Ideal student-teacher relationship does not prevail, teachers have the tendency to scold the students for their wrong doing or learning rather than motivate. Less number of faculties is also barrier. Ethical teachings are not being monitored it needs to be done religiously by the academic council. Motivated and intentional teachers are not being taken as faculties. Selection of students is not proper and selection process of teachers is also not proper. Teachers lack proper training before starting the profession. Theoretically students learns to some extent about ethics, morality and behavioral aspect of patient handling but it's inadequate and does not commensurate in a practical reality. Teachers have shallow and inadequate knowledge about objectives of the curriculum.

\section{Discussion}

In recent years, medicine has begun to advance at a rate that is, at times, difficult to even comprehend. We must acknowledge that improving the care of patients from diverse populations starts with education. Medical students should be taught to identify and treat the patients who actually live in their communities.

As Wendland and Bandawe (2007) said most students begins medical schools with idealistic notions about helping people. By graduation, they became emotionally detached, cynical, mercenary, conservative, and inescapably reductionisitic in their vision of both human body and the processes used to heal it. Total 712 undergraduate medical students participated in this survey to answer the questionnaire .Out of which 473(66.4) were female and 239 (33.6) were male. This is fairly equivalent to the general trend of the medical admission in Bangladesh. Male female ratio in both public and private medical colleges reflects the same. This is a positive development reflecting the women's increasing progress in the society despite of many obstacles.

Dennis (1998) suggested "The personal and professional attributes expected of physicians do not evolve simply because a person selects medicine as a career." This attributes must be fostered among the students cautiously and consciously. This study reveals that participants (65.2) have been taught about the ethical standards in patients care. Mean score of this response is 4.59, which indicates the respondents' perception was positive. In regards to Geneva declaration and Hippocratic Oath, this study reveals 59.1\% participant strongly agreed that they have learnt about it. The mean value of this response is 4.46 which is satisfactory and indicates positive perception. A patient is a whole human being; he is just not an outer wrapping of a disease. A patient deserves respect as an individual. His mind, body and spirits are interrelated affected by his family or societal bindings. This nonmedical problems affects the whole recovery process. In our survey, participants (50.6) learnt to understand patients' non-medical problems which are satisfactory by the mean score of 4.38. Martin (1989) reported that More than half $(55 \%)$ of the patients who discussed a problem with the doctor reported that the discussion was helpful. Islam and Jhora (2012) cited about a small study done in a renowned post graduate institute of the country reveals that during taking history among thirty patients, the socio-economic status is noted only in two cases. None understanding of the socio economic conditions of the patients, usually labels doctors as greedy and generates a great distance with the society (Islam and Jhora 2012). In this study $70 \%$ of the respondents strongly agreed that they have been taught about respecting the confidentiality which is satisfactory with a mean score of 4.67 and $41.3 \%$ respondents also strongly agreed that they have been adequately briefed about informing treatment plan, investigations and counselling towards patients and relatives. The mean score of this statement is 4.21 which is satisfactory. In this study, $71.1 \%$ participants have the opinion that they have been briefed about unethical behavior in relation to accepting gifts from pharmaceutical companies. The mean score of this item was 3.83 which is satisfactory. A survey of physicians by Brett et al. (2003) also have the similar findings where only about half of respondents found non-educational gifts from pharmaceutical representatives and social events to be moderately to very ethically problematic. That means despite of criticism from the society, physicians have a permissive view about accepting gifts from pharmaceutical companies which needs to be addressed appropriately. As Islam and Jhora (2012) said about doctors of Bangladesh that "Many doctors are reluctant to improve the communication which is one of the crucial elements of treatment".

In the present study, respondents' mentioned that they have been taught about different form of communication which includes, managing angers during adverse situation $(80.5 \%)$, relationship with team members $(84.9 \%)$ and not to criticize the fellow physicians and their prescriptions $(83.9 \%)$. These arena were well addressed by the teachers. The mean score respectively was $3.98,4.09$, and 4.13 which are considered as very satisfactory.

There are situations when students or staffs or patients were humiliated publicly. This creates a permanent scar in the mind of the students. Humiliating patients or staffs by the teacher/doctors in front of the students have a long term effects on the mind of the students. In this study, $70 \%$ respondents noticed humiliation of the students in front of patient, $57 \%$ noticed abusing of staffs and $54 \%$ noticed abusing of patients. Situations when a student, staffs or patients were humiliated or involved in conflicts are really disturbing. These findings are consistent with the findings of Scott et al (2015) where 74\% students experienced teaching by humiliation. Study by Scott et al (2015) also highlighted that physicians and surgeons are not the only hospital staff responsible for mistreating students. 
This affects the individual students learning and mental health. There are also potential negative effects on the patients and attendants who witnessed abusive behavior.

This study attempted to explore the behaviors of 'Role model' as observed by the respondents and make them aware about role model. Among respondents $89.0 \%$ recognized clinical expertise as the highest rated attribute of a role model. This finding is consistent with Masami (2016) who find $90.7 \%$ positive response on clinical expertise. Relationship with the patients (82.6\%), Humanity (77.5\%), Personal attributes (61.4\%), Positive outlook (63.2\%), Good leadership skill $(44.0 \%)$ and life style $(35.5 \%)$ are other important behavioral aspects identified by the respondents. All the findings are consistent with the findings of Masami (2016) except attribute 'life style'. Masami (2016) found $77.3 \%$ recommendation on life style as positive attributes, whereas in our study only $35.5 \%$ considered it as positive attributes. It appears that our respondents are not very much concerned about the life style of a role model.

When they were asked about presence of positive or negative role models, 93.1\% responded 'yes' for positive role models and $76.7 \%$ responded 'yes' for negative role models. A similar finding was revealed by Masami (2016) who found $74 \%$ undergraduate students in McGill university of Canada encounters negative role models. Similar study conducted by Nargis (2013) revealed that, students don't think all teachers' as role model. Same study also supports that students understand the importance of teachers as role model.

Respondent thinks non-supportive sociopolitical environment (53.9\%), lack of competent teachers (49.7\%), lack of role models (47.9\%), non-congenial academic environment (46.2\%), lack of supervision from the authority $(44.5 \%)$ and lack of practical teaching about ethics (44.0\%) are the main barriers to become a noble professional.

\section{Conclusion}

This study reveals most of the asked parameters related to patient care and humanistic attitude was taught to the undergraduate medical students of the selected medical colleges. There are few concerns though in some area like number of role models and presence of negative role models among the teachers. Teachers should be selected following a proper career planning. Regrettably teachers are selected randomly, intentional teachers with commitment will definitely yield better result to groom the undergraduate students with a strong moral and ethical understandings. Teachers should undergo some sort of courses before deployment which will give them an understanding on teaching methodology and capability to foster the medical students of current era.

\section{References}

1. Ashmore RD,Deaux K, Volpe TM. 2004. An Organizing Framework for Collective Identity: Articulation and Significance of Multidimensionality, Psychological
Bulletin, American Psychological Association 130(1)

2. Brett AS, Burr W, Moloo J. 2003. Are Gifts from Pharmaceutical Companies Ethically Problematic? A Survey of Physicians. Arch Intern Med 163:2213-2218

3. Conrad, P 1988, Learning to Doctor: Reflections on recent accounts of the medical school years Journal of Health and Social Behavior 29 (4): 323-332.

4. Coulehan JL, Williams, PC 2000. Professional ethics and social activism: Where have we been? Where are we going? University of Iowa press;

5. Han DS, Cho BH, Bae S, Kim CY, Lee SL. 1996. Professional Socialization of Medical Students. Korean Journal of Preventive Medicine 29(2): 265-276.

6. Dennis KS 1998, Fostering Student Adjustment to Medical School: Evaluation of One Innovative Curricular Approach, Paper presented at the Annual Meeting of the American Educational Research Association, San Diego, CA, April 13-17

7. Goldie, J. 2012, The formation of professional identity in medical students: considerations for educators. Medical Teacher 34(9):641-648.

8. Hass J, Shaffir W 1982, Taking on the Role of Doctor: A Dramaturgical Analysis of Professionalization, Symbolic Interaction 5(2) https://doi.org/10.1525/ si.1982.5.2.187

9. Islam MS, Jhora ST. 2012. Physician-Patient Relationship: The Present Situation and Our Responsibilities: Bangladesh Medical Journal 41(1)

10. Scott KM, Caldwell PHY, Barnes EH, Barrett J. 2015, and Teaching by humiliation" and mistreatment of medical students in clinical rotations: a pilot study, MJA 203 (4), 17 August, doi: 10.5694/mja15.00189

11. Martin FJ, Bass MJ 1989. The Impact of Discussion of Non-Medical Problems in the Physicians' office, Family Practice. 6(4):254-258,

12. Masami T. 2016. Effects of undergraduate medical students 'individual attributes on perceptions of encounters with positive and negative role models, BMC Medical Education 16:164 DOI 10.1186/s12909016-0686-1

13. Nargis T. 2013. The hidden curriculum in under graduate medical education in Bangladesh: medical students' perception. Bangladesh Journal of Medical Education 4 (1)

14. Wendland C, Bandawe C. A 2007, Qualitative Study of Medical Student Socialization in Malawi's College of Medicine: Preclinical Training and Identity, Malawi Medical Journal 19(2):68-71 uccess story? Med J Austral 2005; 183, 258-60 